\title{
PENGARUH PENERAPAN SISTEM AKUNTANSI PEMERINTAH DAERAH DAN KUALITAS SUMBERDAYA MANUSIA TERHADAP KUALITAS LAPORAN KEUANGAN PEMERINTAH KABUPATEN GOWA
}

\author{
Ansir Launtu \\ STIEM Bongaya Makassar \\ Email:anslau08@gmail.com
}

\begin{abstract}
Abstrak
Penelitian ini bertujuan untuk menguji dan menganalisis Pengaruh Penerapan Sistem Akuntansi Pemerintah Daerah dan Kualitas Sumber Daya Manusia terhadap Kualitas Laporan Keuangan Pemerintah Kabupaten Gowa. Pengumpulan data menggunakan data primer yang diperoleh dari kuesioner dengan menggunakan teknik purposive sampling. Populasinya adalah SKPD Kabupaten Gowa dengan jumlah 52 SKPD, sedangkan sampel yang diambil berjumlah 25 SKPD berbentuk dinas dan berjumlah 72 responden. Hasil kuesioner telah diuji validitas dan reliabilitas, juga telah diuji asumsi klasik berupa asumsi normalitas dan multikolonieritas. Metode analisis data menggunakan teknik regresi berganda. Hasil penelitian menunjukkan bahwa secara parsial dan simultan penerapan sistem akuntansi pemerintah daerah dan kualitas sumber daya manusia berpengaruh positif dan signifikan terhadap kualitas laporan keuangan pemerintah Kabupaten Gowa.
\end{abstract}

Kata Kunci : Penerapan Sistem Akuntansi Pemerintah Daerah, Kualitas Sumber Daya Manusia, Kualitas Laporan Keuangan.

\section{ABSTRACT}

This study aims to test and analyze the effect of the application of the Regional Government Accounting System and the Quality of Human Resources on the Quality of the Financial Statements of the Gowa Regency Government. Collecting data using primary data obtained from questionnaires by using purposive sampling technique. The Populations are SKPD in Gowa Regency with a total of 52 SKPD, while the samples taken were 25 SKPD in the form of service and there were 72 respondents. The results of the questionnaire have been tested for validity and reliabilit, also has tested the assumptions of classical form of the assumptions of normality and multikolonieritas. Methods of data analysis using multiple regression techniques. The results showed that partially and simultaneously the application of the Regional Government Accounting System and the quality of human resources had a positive and significant effect on the quality of the financial statements of the Gowa Regency government.

Key Words : Application Regional Government Accounting System, Quality of Human Resources, Quality of Finance Report Government.

\section{PENDAHULUAN}

Otonomi daerah telah digulirkan di Indonesia sejak tahun 1999 dengan dikeluarkannya UU Nomor 22 Tahun 1999, disadari bahwa isi UU Nomor 22 Tahun 1999 sudah tidak sesuai lagi dengan perkembangan keadaan, ketatanegaraan, dan tuntutan penyelenggaran otonomi daerah yang lebih efisien. Dengan demikian, dikeluarkanlah undang-undang pengganti yaitu ditetapkannya UU Nomor 32 Tahun 2004 tentang Pemerintah Daerah dan UU Nomor 33 Tahun 2004 tentang Perimbangan Keuangan antara Pemerintah Pusat dan Pemerintah Daerah. Perubahan-perubahan mendasar tersebut telah meningkatkan pengelolaan keuangan daerah. Untuk maksud tersebut pemerintah telah menerbitkan Peraturan Pemerintah (PP) Nomor 58 Tahun 
2005 tentang pengelolaan keuangan daerah sebagai pembaharuan dan penyempurnaan dari Peraturan Pemerintah sebelumnya.

Akuntansi keuangan daerah tidak dapat dilepaskan dari definisi akuntansi sebagai alat komunikasi bisnis. Menurut Abdul Halim (2010) definisi akuntansi pemerintah daerah yang disebutnya sebagai Akuntansi Keuangan Daerah adalah proses pengidentifikasian, pengukuran, pencatatan, dan pelaporan transaksi ekonomi (keuangan) dari entitas Pemerintah Daerah (kabupaten, kota atau provinsi) yang dijadikan informasi dalam rangka pengambilan keputusan ekonomi oleh pihak-pihak eksternal entitas Pemerintah Daerah. Menurut Erlina dkk (2015) Akuntansi keuangan daerah adalah akuntansi yang digunakan untuk mencatat peristiwa ekonomi pada entitas ekonomi di lingkungan Pemerintah Daerah. Akuntansi keuangan daerah ini diperlukan sejalan dengan semangat otonomi daerah yang harus mengelola keuangan daerah secara terpisah dari pemerintahan pusat dan sekaligus melaporkan hasilnya secara transparan kepada publik.

Salah satu alat untuk melihat hasil kegiatan keuangan daerah yaitu melihat Laporan Keuangan Pemerintah Daerah (LKPD). Laporan keuangan merupakan suatu cerminan untuk dapat mengetahui apakah suatu pemerintah daerah telah berjalan dengan baik, sehingga pemerintah diharuskan untuk dapat menghasilkan laporan keuangan yang berkualitas. Dalam entitas pemerintahan, untuk menghasilkan laporan keuangan pemerintah daerah yang berkualitas dibutuhkan sumber daya manusia yang memahami dan kompeten dalam akuntansi pemerintahan, keuangan daerah bahkan organisasional tentang pemerintahan Roviyanti (2011). Laporan keuangan yang berkualitas apabila memenuhi karakteristik kualitatif laporan keuangan. Adapun karakteristik kualitatif laporan keuangan pemerintah yang merupakan prasyarat normatif sebagaimana disebutkan dalam Rerangka Konseptual Akuntansi Pemerintahan antara lain relevan (relevance), andal (reliability), dapat dibandingkan (comparability), dan dipahami (understandability). Apabila informasi yang terdapat didalam laporan keuangan pemerintah daerah memenuhi kriteria karakteristik kualitatif laporan keuangan pemerintah seperti yang disyaratkan dalam PP No. 71 Tahun 2010, berarti pemerintah daerah mampu meningkatkan kualitas laporan keuangan pemerintah daerah tersebut (Agum, 2017)

Menurut Syafarudin (2008) dalam Made Ayu dkk (2014) Kualitas sumber daya manusia adalah sebagai kunci keunggulan kompetitif bagi organisasi. Membentuk kompetensi-kompetensi dan komitmen pegawai baik secara individual atau kelompok guna memenuhi kebutuhan organisasi dan mengintegritasikan kopetensi-kompetensi tersebut dalam sistem manajemen yang dijalankan organisasi. Kualitas dan karakteristik pegawai yang diperlukan oleh organisasi pada hakikatnya tidak terlepas dari tantangantantangan bersaing yang akan dihadapi oleh organisasi sekarang maupun di masa yang akan datang. Suatu laporan keuangan haruslah disusun oleh sumber daya manusia dengan kemampuan dibidang akuntansi yang memadai sehingga dapat mengurangi kesalahan perhitungan. Menurut Febriady (2013) dalam jurnal Agum Gumelar (2017), dalam pengelolaan keuangan daerah yang baik, SKPD harus memiliki sumber daya manusia yang berkualitas, yang didukung dengan latar belakang pendidikan akuntansi, sering mengikuti pendidikan dan pelatihan, dan mempunyai pengalaman dibidang keuangan. Sehingga untuk menerapkan sistem akuntansi, sumber daya manusia tersebut akan mampu memahami logika akuntansi dengan baik. Kegagalan sumber daya manusia pemerintah daerah dalam memahami dan menerapkan logika akuntansi akan 
berdampak pada kekeliruan laporan keuangan yang dibuat dan ketidaksesuaian laporan dengan standar yang ditetapkan pemerintah. Agar laporan keuangan dapat dikategorikan berkualitas, maka dalam penyusunan laporan keuangan pemerintah harus dilakukan oleh sumber daya manusia yang mempunyai keahlian yang memadai agar dapat mempercepat dan memperakurat laporan keuangan pemerintah guna menghasilkan laporan keuangan yang berkualitas.

Berdasarkan PP No. 71 Tahun 2010 tentang Standar Akuntansi Pemerintah (SAP) menyatakan bahwa pemerintah menyusun sistem akuntansi pemerintah yang mengacu pada Standar Akuntansi Pemerintah, Sistem akuntansi pemerintah pada tingkat pemerintah pusat diatur dengan peraturan Menteri Keuangan yakni peraturan Menteri keuangan No.59/PMK.06/3005 mengenai sistem akuntansi dan pelaporan keuangan pemerintah pusat, sedangkan sistem akuntansi pemerintahan pada tingkat daerah diatur dengan peraturan Gubernur/Bupati/Walikota, mengacu pada peraturan daerah yang berpedoman pada peraturan pemerintah Nomor 58 Tahun 2005 pasal 99 mengenai pengelolaan keuangan daerah dan juga didukung oleh peraturan menteri dalam negeri Nomor 59 Tahun 2007 tentang pedoman pengelolaan keuangan daerah yaitu pasal 232 yang mengatur tentang Sistem Akuntansi Pemerintah Daerah. Standar akuntansi pemerintah merupakan suatu standar penyusunan laporan keuangan milik pemerintah yang disusun dalam bentuk prinsip-prinsip akuntansi dalam menyusun dan menyajikan laporan keuangan pemerintah.

Menurut Fess dan Warren (1990) dalam Abdul Halim dkk (2010) menyatakan sistem akuntansi adalah sistem yang dapat menyajikan informasi untuk digunakan dalam hubungan bisnis dan pelaporan kepada pemilik, kreditor, dan pihak-pihak lain yang berkepentingan. Sistem akuntansi merupakan rangkaian kegiatan yang dilakukan manajemen untuk menyajikan informasi yang diperlukan oleh pihak-pihak di luar organisasi sesuai dengan prinsip akuntansi berlaku umum. Sistem akuntansi keuangan, atau disebut juga dengan sistem informasi akuntansi keuangan, diperlukan untuk menghasilkan informasi kepada pihak luar sesuai dengan standar. Sistem tersebut disusun untuk dapat mengidentifikasi, mengukur, dan melaporkan transaksi (kejadian ekonomis). Sistem akuntansi keuangan merupakan bagian dari sistem informasi manajemen. Dalam PP Nomor 8 Tahun 2006 tentang Pelaporan Keuangan dan Kinerja Instansi Pemerintah disebutkan bahwa sistem akuntansi pemerintah merupakan rangkaian sistematik dari prosedur, penyelenggara, peralatan, dan elemen lain untuk mewujudkan fungsi akuntansi sejak analsis transaksi sampai dengan pelaporan keuangan di lingkungan organisasi pemerintah. Dengan demikian sistem akuntansi pemerintah adalah sistem pencatatan yang dapat menghasilkan informasi keuangan untuk tujuan inten pemerintah bahkan tujuan luar organisasi.

Dengan demikian, standar akuntansi pemerintah merupakan persyaratan dalam upaya meningkatkan kualitas laporan keuangan pemerintah daerah Dahri, dkk (2015). Guna menghasilkan laporan keuangan yang relevan, handal dan dapat dipercaya, pemerintah daerah harus memiliki sistem akuntansi yang handal. Sistem akuntansi yang lemah menyebabkan laporan keuangan yang dihasilkan juga kurang handal dan kurang di relevan untuk pembuatan keputusan.

Laporan Keuangan Pemerintah Daerah (LKPD) setiap tahunnya dapat penilaian berupa opini dari badan pengawas keuangan (BPK). Terdapat empat opini yang diberikan pemeriksa yaitu : Opini Wajar Tanpa Pengecualian (WTP), Opini Wajar Dengan Pengecualian (WDP), Opini Tidak Wajar (TP), dan Pernyataan Menolak 
Memberi Opini atau Tidak Memberi Pendapat (TMP). Dalam siaran pers yang dipublikasikan oleh BPK provinsi Sulawesi Selatan penyerahan Laporan Hasil Pemeriksaan (LHP) atas Laporan Keuangan Pemerintah Daearah (LKPD) TA 2016 pada Kabupaten Gowa. Hasil pemeriksaan BPK atas Laporan Keuangan Daerah LKPD TA 2016 Kabupaten Gowa, BPK memberikan opini Wajar Tanpa Pengecualian (WTP) yang merupakan pencapaian opini WTP keenam dimana opini yang sama diperoleh LKPD TA 2011, TA 2012, TA 2013, TA 2014 dan TA 2015; http://makassar.bpk.go.id/. Berdasarkan siaran pers yang dipublikasikan oleh BPK atas opini LKPD TA 2016 pada pemerintah Kabupaten Gowa yang mendapatkan 6 (enam) kali berturut-turut Wajar Tanpa Pengecualian (WTP) ini merupakan prestasi yang sangat memuaskan bagi pemerintah Kabupaten Gowa karena pemerintah Kabupaten Gowa yang mampu mempertahankan opini Wajar Tanpa Pengecualian (WTP) yang di berikan BPK.

Dengan mendapatkan opini WTP, tidak semua pemerintah daerah memiliki laporan keuangan yang berkualitas. Banyak ditemukan pemerintah daerah yang mendapatkan opini WTP masih menggunakan sistem akuntasi pemerintah yang tidak menerapkan nya secara tidak merata diseluruh SKPD. Artinya bahwa di seluruh SKPD ada sebagian yang masih menggunakan proses yang secara manual dan ada yang menggunakan proses yang secara komputerisasi. Dan itu akan membuat laporan yang dilakukan akan terlambat. Begitu pula dengan sumber daya manusia juga memberi kontribusi sangat berarti pada kualitas laporan keuangan. Namun masih banyak ditemukan sumber daya manusia yang tidak memiliki pendidikan terakhir yang sesuai dengan pekerjaan dan tanggung jawabnya dan kurangnya pemahaman tentang SAP yang diatur dalam PP No. 71 Tahun 2010.

Beberapa penelitian terdahulu terkait pengaruh penerapan sistem akuntansi pemerintah daerah terhadap kualitas laporan keuangan antara lainnya dari A. Dahri, dkk (2015), tentang "Pengaruh Penerapan Sistem Akuntansi Keuangan Pemerintah Daerah Terhadap Kualitas Laporan Keuangan Pemerintah Daerah" yang menemukan bahwa penerapan sistem akuntansi keuangan pemerintah daerah berpengaruh positif terhadap kualitas laporan keuangan pemerintah daerah. Adapun penelitian Zarzani (2016), tentang "Analisis Penerapan Sistem Akuntansi Keuangan Daerah pada SKPD Pemerintah Aceh (Studi Pada Dinas Tenaga Kerja dan Mobilitas Penduduk Aceh) hasil penelitian nya menunjukkan bahwa Penerapan Sistem Akuntansi Keuangan Daerah pada SKPD Pemerintah Aceh belum optimal dan masih perlu ditingkatkan. Agum (2017) dalam penelitiannya, "Pengaruh Kualitas Sumber Daya Manusia, Penerapan Standar Akuntansi Pemerintah dan Sistem Pengendalian Intern terhadap Kualitas Laporan Keuangan Pemerintah Daerah (Studi Empiris pada SKPD Kabupaten Kerinci)", yang menemukan bahwa antara kualitas sumber daya manusia dengan kualitas laporan keuangan pemerintah daerah ialah positif. Hal ini sejalan dengan pernyataan Roviyanti (2011), yang menyebutkan bahwa laporan laporan keuangan merupakan sebuah produk yang dihasilkan oleh bidang atau disiplin ilmu

Penerapan Sistem Akuntansi Keuangan Daerah (X1) dalam Permendagri Nomor 21 Tahun 2011 adalah serangkaian prosedur mulai dari proses pengumpulan data, pencatatan, pengikhtisaran, sampai dengan pelaporan keuangan, dalam rangka pertanggungjawaban pelaksana APBD yang dapat dilakukan secara manual atau menggunakan aplikasi komputer. Indikator yang digunakan dalam penerapan sistem akuntansi Pemerintah Daerah (X1), adalah : Kesesuaian sistem akuntansi keuangan dengan SAP, prosedur pencatatan akuntansi dengan pencatatan standar akuntansi yang 
berlaku umum, dan pembuatan laporan keuangan yang dilaporkan secara periodik. Berbeda dengan indikator yang digunakan oleh Zarzani (2016) dengan judul Analisis Penerapan Sistem Akuntansi Keuangan Daerah Pada SKPD Pemerintah Aceh (Studi Pada Dinas Tenaga Kerja dan Mobilitas Penduduk Aceh), berdasarkan elemen sistem akuntansi keuangan daerah tersebut, maka dapat disusun indikator sistem akuntansi keuangan daerah, adalah: Kesesuaian sistem dengan SAP, Pengidentifikasian transaksi, pencatatan transaksi, bukti disetiap transaksi, pencatatan kronologis, pengklasifikasian transaksi, laporan keuangan setiap periode, dan pelaporan yang konsisten dan periode. Hal yang mendasar mempengaruhi kualitas laporan keuangan pemerintah daerah adalah penerapan sistem akuntansi pemerintah daerah berdasarkan standar akuntansi pemerintah daerah yang bertujuan untuk meningkatkan akuntabilitas dan keandalan pengelola keuangan pemerintah melalui penyusunan dan pengembangan standar akuntansi pemerintah. Menurut Galuh (2011) dalam Agung (2015) Kualitas sumber daya manusia (X2) adalah kemampuan sumber daya manusia untuk melaksanakan tugas dan tanggungjawab yang diberikan kepadanya dengan bekal pendidikan, pelatihan, dan pengalaman yang cukup memadai. Indikator yang digunakan dalam kualitas sumber daya manusia adalah kemampuan perencanaan/pengorganisasian, pengetahuan, kemampuan, semangat kerja. Hal ini tidak sejalan dengan indikator peneliti Agum (2017) dengan judul Pengaruh Kualitas Sumber Daya Manusia, Penerapan Standar Akuntansi Pemerintahan dan Sistem Pengendalian Intern terhadap Kualitas Laporan keuangan Pemerintah Daerah (Studi Empiris Pada SKPD Kabupaten Kerinci), berdasarkan hal tersebut indikator yangdigunakan, adalah kemampuan perencanaan/pengorganisasian, pengetahuan, kemampuan, semangat kerja.Sumber daya manusia yang didukung dengan latar belakang pendidikan, pelatihan dan memiliki pengalaman dibidang keuangan dalam menerapkan sistem akuntansi, sumber daya yang berkualitas tersebut akan mampu memahami logika akuntansi yang baik dan terwujudnya laporan keuangan yang berkualitas karena disusun sesuai standar akuntansi pemerintah. Tujuan penelitian ini adalah untuk menguji dan menganalisis pengaruh penerapan sistem akuntansi Pemerintah Daerah dan kualitas sumber daya manusia baik secara parsial maupun simultan terhadap kualitas laporan keuangan pemerintah Kabupaten Gowa.

\section{METODOLOGY}

Penelitian ini menggunakan pendekatan penelitian kuantitatif dengan logika/penalaran deduktif kuantitatif, dan juga menggunakan jenis penelitian deskriptif. Populasi dalam penelitian ini adalah seluruh satuan kerja perangkat daerah (SKPD) pemerintah Kabupaten Gowa, PERDA No. 11 Tahun (2016) tentang Pembentukan dan Susunan Perangkat Daerah Pemerintah Kabupaten Gowa. Kriteria sampel yang digunakan dalam penelitian ini adalah SKPD Berbentuk Dinas Daerah yaitu kepala sub bagian keuangan, bendahara dan staf bagian keuangan yang menyusun laporan yang berkaitan dengan laporan keuangan di masing-masing dinas. Jumlah sampel secara keseluruhan yaitu 75. Jenis Data yang digunakan meliputi data kuantitatif. Sumber Data yang digunakan dalam penelitian ini adalah Data Primer. Data Primer adalah data yang diperoleh langsung di Satuan Kerja Perangkat Daerah (SKPD) berbentuk Dinas Daerah dengan melakukan penyebaran kuesioner kepada pegawai yang menjadi responden. Dalam penelitian ini, peneliti menggunakan teknik pengumpulan data dengan menggunakan kuesioner yang didistribusikan secara langsung di Satuan Kerja 
Perangkat Daerah (SKPD) berbentuk Dinas Daerah. Adapun metode skala pengukuran yang digunakan penulis dalam penelitian ini adalah skala likert. Metode analisis dalam penelitian ini adalah analisis statitistik deskriptif dengan menjelaskan,meringkas,menggambarkan data kebentuk yang teratur sehingga muda di pahami dan disimpulkan. Metode analisis lainnya yakni analisis statistik inferensial dengan menggunakan analisis regresi berganda, secara kuantitatif dengan pengujian uji t dan uji $\mathrm{f}$ untuk menganalisis pengaruh penerapan sistem akuntansi Pemerintah Daerah dan kualitas sumber daya manusia terhadap Kualitas Laporan Keuangan Pemerintah Daerah pemerintah Kabupaten Gowa

Defenisi operasional dari setiap variabel dapat dijelaskan dibawah ini Penerapan Sistem Akuntansi Pemerintah Daerah (X1) adalah serangkaian prosedur manual maupun yang terkomputerisasi mulai dari pengumpulan data, pencatatan, pengikhtisaran, serta pelaporan posisi keuangan dan operasi keuangan pemerintah daerah. Dengan indikator 1. Kesesuaian Sistem Akuntansi Keuangan dengan SAP, 2. Prosedur pencatatan akuntansi dengan pencatatan standar akuntansi yang berlaku umum dan 3. Pembuatan laporan keuangan yang dilaporkan secara periode (Dhedy Triwardana, 2017). Kualitas Sumber Daya Manusia (X2) adalah kemampuan sumber daya manusia untuk melaksanakan tugas dan tanggung jawab yang diberikan kepadanya dengan bekal profesionalisme, pengetahuan, kemampuan, semangat kerja, dan kemampuan perencanaan/pengorganisasian. Dengan indikator 1. Memahami bidangnya masing-masing, 2. Pengetahuan, 3. Kemampuan,4.SemangatKerja dan 5. Kemampuan perencanaan/pengorganisasian. (Hutopea dan Nurianna 2006). Kualitas Laporan Keuangan Pemerintah Daerah (Y) adalah informasi yang disajikan dalam laporan keuangan tersebut dapat dipahami dan memenuhi kebutuhan pemakainya dalam pengambilan keputusan, bebas dari pengertian yang menyesatkan dan kesalahan material serta dapat diandalkan, sehingga laporan keuangan tersebut dapat dibandingkan dengan periode-periode sebelumnya. Dengan indikator 1. Andal, 2.Relevan, 3.Dapat dibandingkan 4. Dapat dipahami, (Pemerintah Daerah PP No. 71 Tahun 2010)

\section{HASIL PENELITIAN DAN PEMBAHASAN}

Pengujian validitas dalam penelitian ini menggunakan teknik koofisien korelasi lebih besar atau sama dengan 0,30 dikatakan valid. Dengan menggunakan SPSS 23 for windows maka hasil pengujian validitas terhadap enam instrumen pernyataan variabel penerapan sistem akuntansi pemerintah daerah (X1), enam instrumen pernyataan variabel kualitas sumber daya manusia (X2) dan delapan instrumen pernyataan variabel kualitas laporan keuangan (Y) ketiga variabel ini memiliki nilai $r$ hitung lebih besar dari 0,30, sehingga dapat dikatakan semua item pernyataan adalah valid. Begitupun pengujian reliabilitas angka-angka dari nilai alpha cronbach's pada seluruh variabel dalam penelitian ini semua menunjukkan besarnya diatas nilai 0,60 . Hal ini berarti bahwa seluruh pernyataan untuk variabel independen dan dependen adalah reliabel dan dapat disimpulkan bahwa instrumen pernyataan kuesioner menunjukkan kehandalan dalam mengukur variabelvariabel dalam model penelitian.

Variabel penerapan sistem akuntansi pemerintah daerah mempunyai nilai standar deviasinya $(4,18835)$ dan nilai mean $(24,0833)$, variabel kualitas sumber daya manusia mempunyai nilai standar deviasi $(3,34057)$ dan nilai mean $(24,3472)$, dan variabel 
kualitas laporan keuangan mempunyai nilai standar deviasinya $(3,87833)$ dan nilai mean $(33,9722)$ Dengan demikian dapat disimpulkan bahwa semua variabel tidak terjadi outliers pada data, karena nilai standart deviasi kurang dari nilai mean. Dalam rangka menguji Pengaruh Penerapan Sistem Akuntansi Pemerintah Daerah dan Kualitas Sumber Daya Manusia terhadap Kualitas Laporan Keuangan Pemerintah Kabupaten Gowa, maka digunakan analisis regresi berganda. Perhitungan dilakukan dengan bantuan program SPSS versi 23 for windows dan diperoleh hasil sebagai berikut:

Tabel 1. Hasil analisis regresi berganda

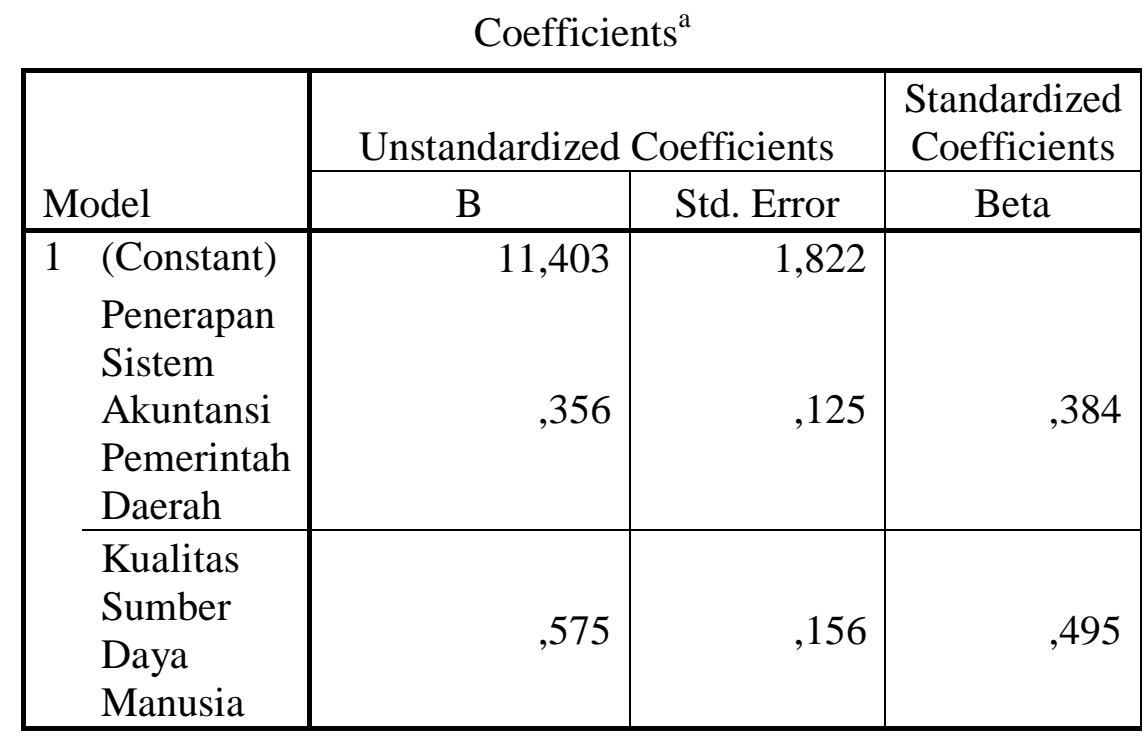

Sumber : Data primer diolah.

Dari tabel di atas dapat diketahui bahwa persamaan regresi berganda pada penelitian ini adalah sebagai berikut :

$$
\mathrm{Y}=11,403+0,356 \mathrm{X} 1+0,575 \mathrm{X} 2
$$

Dari persamaan regresi tersebut, dapat diketahui bahwa koefisien intercept (a) dari persamaan di atas adalah sebesar 11,403 yang mengandung pengertian bahwa pada saat tingkat penerapan sistem akuntansi Pemerintah Daerah (X1) dan kualitas sumber daya manusia (X2) tetap, maka tingkat perolehan kualitas laporan keuangan (Y) adalah sebesar 11,403. Dari persamaan di atas juga dapat diketahui bahwa jika penerapan sistem akuntansi pemerintah daerah (X1) naik sebesar 1\% sedang variabel lain dianggap konstan maka tingkat kualitas laporan keuangan (Y) akan naik sebesar 0,356. Jika kualitas sumber daya manusia (X2) naik 1\% sedang variabel lain dianggap konstan, maka tingkat kualitas laporan keuangan (Y) akan naik sebesar 0,575. Hasil analisis regresi linear berganda memberikan gambaran bahwa variabel penerapan sistem akuntansi Pemerintah Daerah dan kualitas sumber daya manusia memiliki hubungan yang positif terhadap kualitas laporan keuangan. 
Tabel 2. Hasil uji t (Parsial)

\begin{tabular}{|ll|r|r|}
\hline & & \\
Model & \multicolumn{1}{c|}{$\mathrm{t}$} & \multicolumn{1}{c|}{ Sig. } \\
\hline $1 \quad$ (Constant) & 6,259 &, 000 \\
& Penerapan Sistem Akuntansi & 2,852 &, 006 \\
Pemerintah Daerah & 3,675 &, 000 \\
\hline \multicolumn{2}{|l|}{ Kualitas Sumber Daya Manusia } & \\
\hline
\end{tabular}

a. Dependent Variabel: Kualitas Laporan Keuangan

Sumber : Data primer diolah

1) Pengaruh Penerapan Sistem Akuntansi Pemerintah Daerah (X1) terhadap Kualitas Laporan Keuangan (Y)

Berdasarkan tabel diatas dimana nilai $\mathrm{t}$ hit untuk variabel Penerapan Sistem Akuntansi Pemerintah Daerah sebesar 2,852 dan signifikan pada tingkat kepercayaan $(a=0,05)$, nilai signifikan yang diperoleh sebesar 0,006 lebih kecil dari 0,05 . Nilai t $t a b$ dengan $\mathrm{a}=0,05$ dan derajat bebas $=72-1-1=70$ maka diperoleh nilai t $t a b 1,994$. Oleh karena itu nilai t hit untuk koofisien variable Penerapan Sistem Akuntansi Pemerintah Daerah sebesar 2,852 lebih besar dari t tab sebesar 1,994 maka pada tingkat kekeliruan $5 \% \mathrm{Ho}_{1}$ ditolak dan $\mathrm{Ha}_{1}$ diterima. Artinya variabel Penerapan Sistem Akuntansi Pemerintah Daerah (X1) berpengaruh positif dan signifikan terhadap kualitas laporan keuangan (Y).

\section{2) Pengaruh Kualitas Sumber Daya Manusia (X2) terhadap Kualitas Laporan Keuangan (Y)}

Berdasarkan tabel diatas dimana nilai t hit untuk variabel kualitas sumber daya manusia sebesar 3,675 dan signifikan pada tingkat kepercayaan $(a=0,05)$, nilai signifikan yang diperoleh sebesar 0,000 lebih kecil dari 0,05. Nilai t tab dengan $\mathrm{a}=$ 0,05 dan derajat bebas $=72-1-1=70$ maka diperoleh nilai t tab 1,994. Oleh karena itu nilai t hit untuk koofisien variabel kualitas sumber daya manusia sebesar 3,675 lebih besar dari t tab sebesar 1,994 maka pada tingkat kekeliruan $5 \% \mathrm{Ho}_{2}$ ditolak dan $\mathrm{Ha}_{2}$ diterima. Artinya variabe kualitas sumber daya manusia 1 (X2) berpengaruh positif dan signifikan terhadap kualitas laporan keuangan (Y).

\section{3) Pengaruh Penerapan Sistem Akuntansi Pemerintah Daerah (X1) dan Kualitas Sumber Daya Manusia (X2) terhadap Kualitas Laporan Keuangan (Y)}

Uji simultan atau Uji F merupakan uji secara simultan untuk menguji signifikan pengaruh variabel Penerapan Sistem Akuntansi Pemerintah Daerah dan Kualitas Sumber Daya Manusia terhadap Kualitas Laporan Keuangan Pemerintah Kabupaten Gowa. 


\section{Tabel 3. Hasil uji F (Simultan)}

\begin{tabular}{|c|c|c|c|c|c|c|}
\hline \multicolumn{7}{|c|}{$\mathrm{ANOVA}^{\mathrm{a}}$} \\
\hline \multicolumn{2}{|c|}{ Model } & $\begin{array}{c}\text { Sum of } \\
\text { Squares }\end{array}$ & Df & $\begin{array}{l}\text { Mean } \\
\text { Square }\end{array}$ & $\mathrm{F}$ & Sig. \\
\hline \multirow[t]{3}{*}{1} & Regression & 779,757 & 2 & 389,879 & 93,348 &, $000^{b}$ \\
\hline & Residual & 288,187 & 69 & 4,177 & & \\
\hline & Total & 1067,944 & 71 & & & \\
\hline
\end{tabular}

a. Dependent Variable: Kualitas Laporan Keuangan

b. Predictors: (Constant), Kualitas Sumber Daya Manusia, Penerapan Sistem Akuntansi Pemerintah Daerah

Sumber : Data primer diolah.

Berdasarkan tabel di atas dimana nilai $\mathrm{F}$ hit sebesar 93,348 dan dari nilai $\mathrm{F}$ tab pada tingkat kepercayaan $95 \%$ dan derajat bebas $(2: 72)$ yang diperoleh dari $(\mathrm{k}: \mathrm{n}-\mathrm{k}-1)$ $(2: 72-2-1=69)$ maka diperoleh nilai $\mathrm{F}$ tab $=3,129$. Oleh karena itu nilai $\mathrm{F}$ hit 93,348 lebih besar dibanding nilai $\mathrm{F}$ tab 3,129 dengan tingkat kepercayaan 95\% dan derajat kekeliruan 5\% (a = 0,05) $\mathrm{Ho}_{3}$ ditolak dan $\mathrm{H} a_{3}$ diterima. Artinya variabel penerapan sistem akuntansi Pemerintah Daerah (X1) dan kualitas sumber daya manusia (X2) secara simultan berpengaruh positif dan signifikan terhadap kualitas laporan keuangan (Y)

Koofisien determinasi $\left(\mathrm{R}^{2}\right)$ menunjukkan besarnya pengaruh variabel independen secara bersama-sama terhadap variabel. Dalam hal ini koofisien determinasi dicari untuk mengetahui seberapa besar perubahan dari kualitas laporan keuangan yang dapat dijelaskan oleh variasi penerapan sistem akuntansi pemerintah daerah dan kualitas sumber daya manusia secara bersama-sama (simultan). Tabel model summary sebagai berikut :

Tabel 4. Koofisien Determinasi $\left(\mathbf{R}^{2}\right)$ Model Summary

\begin{tabular}{|c|c|c|c|c|}
\hline Model & $\mathrm{R}$ & R Square & $\begin{array}{c}\text { Adjusted } \\
\text { R } \\
\text { Square }\end{array}$ & Std. Error of the Estimate \\
\hline 1 & $854^{\mathrm{a}}$ & $\overline{7730}$ &, 722 & 2,04368 \\
\hline
\end{tabular}

a. Predictors: (Constant), Kualitas Sumber Daya Manusia, Penerapan Sistem Akuntansi Pemerintah Daerah

Sumber : Data primer diolah.

Berdasarkan Tabel diatas dapat diketahui nilai $\mathrm{R}$ Square sebesar 0,730. Berdasarkan nilai R Square (R2) ini dapat diketahui bahwa sebesar $73 \%$ variasi perubahan kualitas laporan keuangan yang dapat dijelaskan oleh penerapan sistem akuntansi pemerintah daerah dan kualitas sumber daya manusia secara bersama-sama, sedangkan variasi kualitas laporan keuangan yang tidak dapat dijelaskan oleh penerapan sistem akuntansi Pemerintah Daerah dan kualitas sumber daya manusia tetapi bisa 
dijelaskan oleh sebab-sebab yang lain di luar model lain sebesar 27\% (100\% - 73\%). Uji statistik t pada dasarnya menunjukkan seberapa jauh pengaruh satu variabel bebas (independent) secara parsial atau individual dalam mempengaruhi variabel tidak bebas (dependent)

\section{PEMBAHASAN}

a. Pengaruh Penerapan Sistem Akuntansi Pemerintah Daerah secara parsial terhadap Kualitas Laporan Keuangan Pemerintah Kabupaten Gowa.

Hipotesis pertama yang diajukan secara parsial yaitu $\mathrm{H}_{1}$ : Penerapan Sistem Akuntansi Pemerintah Daerah berpengaruh positif terhadap Kualitas Laporan Keuangan Pemerintah Kabupaten Gowa. Hasil statistik yang telah dilakukan memiliki nilai nilai t hit sebesar 2,852 lebih besar dari nilai t tab 1,994 dan nilai signifikan yang dihasilkan yakni 0,006 lebih kecil dari nilai 0,05 maka $\mathrm{Ho}_{1}$ ditolak dan $\mathrm{H} a_{1}$ diterima. Dengan demikian hipotesis yang diajukan diterima ini terbukti dari hipotesis yang dihasilkan Penerapan Sistem Akuntansi Pemerintah Daerah berpengaruh positif dan signifikan terhadap Kualitas Laporan Keuangan Pemerintah Kabupaten Gowa.

Artinya dengan diterapkan nya sistem akuntansi pemerintah daerah yang sesuai dengan SAP yang tercantum dalam PP Nomor 71 Tahun 2010, prosedur pencatatan akuntansi dengan pencatatan standar akuntansi yang berlaku secara umum, dan pembuatan laporan keuangan yang dilaporkan secara periode maka akan menghasilkan output yang baik dan berkualitas yaitu laporan keuangan yang berkualitas. Untuk menghasilkan laporan keuangan yang relevan, andal, dapat dipahami dan dapat dibandingkan pemerintah daerah harus menerapkan sistem akuntansi yang baik dan handal. Pada pemerintah Kabupaten Gowa telah menerapkan sistem akuntansi pemerintah daerah yang dikenal dengan sebutan SIMDA. Sistem tersebut digunakan diseluruh SKPD pemerintah Kabupaten Gowa. Dengan adanya dan digunakan sistem tersebut dengan sesuai karakteristik maka akan menghasilkan laporan keuangan yang berkualitas sesuai dengan LKPD opini BPK yang mendapatkan 6 (enam) kali berturutturut. Penelitian ini juga didukung oleh A. Dahri (2015) hasil penilitiannya menunjukkan bahwa Penerapan Sistem Akuntansi Keuangan Pemerintah Daerah berpengaruh positif terhadap Kualitas Laporan Keuangan.

\section{b. Pengaruh Kualitas Sumber Daya Manusia secara parsial terhadap Kualitas Laporan Keuangan Pemerintah Kabupaten Gowa.}

Hipotesis kedua yang diajukan secara parsial yaitu $\mathrm{H}_{2}$ : Kualitas Sumber Daya Manusia berpengaruh positif terhadap Kualitas Laporan Keuangan Pemerintah Kabupaten Gowa. Hasil statistik yang telah dilakukan memiliki nilai nilai t hit sebesar 3,675 lebih besar dari nilai t tab 1,994 dan nilai signifikan yang dihasilkan yakni 0,00 lebih kecil dari nilai 0,05 maka $\mathrm{Ho}_{2}$ ditolak dan $\mathrm{Ha}_{2}$ diterima. Dengan demikian hipotesis yang diajukan diterima ini terbukti dari hipotesis yang dihasilkan menunjukkan kualitas sumber daya manusia berpengaruh positif dan signifikan terhadap Kualitas Laporan Keuangan Pemerintah Kabupaten Gowa. Artinya Sumber daya manusia yang berkualitas dimana sumber daya manusia yang memiliki kemampuan perencanaan/pengorganisasian, pengetahuan, kemampuan yang secara general atau umum yang dimiliki sumber daya mansuia, memiliki semangat kerja yang tinggi, dan sumber daya manusia yang mampu memahami bidangnya masing-masing 
(profesionalisme). Berdasarkan hasil penelitian bahwa sumber daya manusia yang dimiliki Pemerintah Kabupaten Gowa memiliki standar atau ketentuan tersebut.. Yang dimana sumber daya manusia pemerintah Kabupaten Gowa memiliki pengetahuan yang baik mengenai keuangan sehingga mampu mengelola atau menghasilkan outout berupa laporan keuangan yang berkualitas, meskipun mereka memiliki tugas dibagian keuangan namun pendidikan terakhirnya tidak sejalan dengan tugas dan tanggung jawab nya. Tetapi sumber daya manusia tersebut memiliki tingkat pendidikan yang memadai yaitu dominan dengan lulusan $\mathrm{S} 1$, sehingga para pegawai memiliki kemampuan penalaran yang baik untuk cepat mempelajari hal-hal baru dan para pegawai juga sering mengikuti pelatihan dan seminar yang berhubungan dengan keuangan, memiliki semangat kerja, dan bersikap profesionalisme dalam melaksanakan tugas dan tanggungjawabnya. Tapi adapun beberapa pegawai yang memiliki latar belakang pendidikan yang sudah sesuai dengan penempatanya. Penelitian ini juga didukung oleh Agum Gumelar (2017) hasil penilitiannya menunjukkan bahwa terdapat pengaruh yang signifilkan antara kualitas sumber daya manusia dengan kualitas laporan keuangan pemerintah daerah dan hubungannya positif.

\section{c. Pengaruh Penerapan Sistem Akuntansi Pemerintah Daerah dan Kualitas Sumber Daya Manusia secara simultan terhadap Kualitas Laporan Keuangan Pemerintah Kabupaten Gowa.}

Hipotesis ketiga yang diajukan secara simultan adalah $\mathrm{H}_{3}$ : Penerapan Sistem Akuntansi Pemerintah Daerah dan Kualitas Sumber Daya Manusia secara simultan berpengaruh positif terhadap Kualitas Laporan Keuangan Pemerintah Kabupaten Gowa. Hasil statistik yang telah dilakukan memiliki nilai $\mathrm{F}$ hit 93,348 lebih besar dibanding nilai $\mathrm{F}$ tab 3,129 dan nilai signifikan yang dihasilkan yakni 0,000 lebih kecil dari nilai 0,05 maka $\mathrm{Ho}_{3}$ ditolak dan $\mathrm{Ha}_{3}$ diterima. Dengan demikian hipotesis yang diajukan diterima ini terbukti dari hipotesis yang dihasilkan menunjukkan Penerapan Sistem Akuntansi Pemerintah Daerah dan Kualitas Sumber Daya Manusia secara simultan berpengaruh positif dan signifikan terhadap Kualitas Laporan Keuangan Pemerintah Kabupaten Gowa. Artinya berdasarkan hasil penelitian untuk menghasilkan laporan keuangan yang berkualitas dengan karakteristik relevan, andal, dapat dipahami dan dapat dibandingkan dibutuhkan sumber daya manusia yang berkualitas dengan memiliki karakteristik memiliki kemampuan perencanaan/pengorganisasian, pengetahuan, kemampuan secara general atau umum, semangat kerja, dan memiliki sikap profesionalisme dalam memahami tugas dan tanggung jawabnya masing-masing. Dengan memiliki karakteristik tersebut sumber daya manusia yang berkualitas mampu menerapkan sistem akuntansi pemerintah daerah yang sesuai dengan SAP yang berlaku pada PP Nomor 71 Tahun 2010, prosedur pencatatan akuntansi dengan pencatatan standar akuntansi yang berlaku secara umum, dan pembuatan laporan keuangan yang dilaporkan secara periode sehingga menghasilkan output berupa laporan keuangan yang berkualitas. Pada pemerintah Kabupaten Gowa sumber daya manusia atau pegawai memiliki kemampuan memahami dan telah menerapkan sistem akuntansi pemerintah daerah tersebut sehingga laporan keuangan pemeritah Kabupaten Gowa dikatakan berkualitas dengan mendapatkan opini WTP 6 (enam) kali berturut-turut.

\section{KESIMPULAN}

Berdasarkan hasil penelitian di tarik sebuah kesimpulan sebaga berikut : 
1. Penerapan Sistem Akuntansi Pemerintah Daerah berpengaruh positif dan signifikan terhadap Kualitas Laporan Keuangan Pemerintah Kabupaten Gowa.

2. Kualitas Sumber Daya Manusia berpengaruh positif dan signifikan terhadap Kualitas Laporan Keuangan Pemerintah Kabupaten Gowa.

3. Penerapan Sistem Akuntansi Pemerintah Daerah dan Kualitas Sumber Daya Manusia secara simultan berpengaruh positif dan signifikan terhadap Kualitas Laporan Keuangan Pemerintah Kabupaten Gowa.

\section{DAFTAR PUSTAKA}

A. Dahri Adi Patra, Lanteng Bustam, dan Hasriani. (2015). Pengaruh Penerapan Sistem Akuntansi Keuangan Pemerintah Daerah Terhadap Kualitas Laporan Keuangan Pemerintah Daerah.

Bastian, Indra. (2010). Akuntansi Sektor Publik Suatu Pengantar Edisi Ketiga. Jakarta: Erlangga.

Badan Pemeriksa Keuangan Republik Indonesia Perwakilan Provinsi Sulawesi Selatan, http://makassar.bpk.go.id/ diakses pada tanggal 4 Maret 2019

Doni Juni Priansa 2014, Perencanaan dan Pengembangan SDM. Bandung: Alfabeta.

Erlina, Omar Sakti Rambe, dan Rasdianto. (2015). Akuntansi Keuangan Daerah Berbasis Akrual. Edisi Pertama. Jakarta: Salemba Empat (PT salemba emban patria).

Faud, Ramli. (2015). Pengantar Akuntansi Keuangan Daerah. Bogor: Ghalia Indonesia.

Firdaus, Nadirsyah, dan Heru Fahelvi. (2015). Pengaruh Kualitas Sumber Daya Manusia Pemanfaatan Teknologi Informasi Dan Penerpan Kebijakan Akuntansi Terhadap Kualitas Laporan Keuangan Pemerintah Kota Banda Aceh.

Gumelar, Agum. (2017). Pengaruh Kualitas Sumber Daya Manusia, Penerapan Standar Akuntansi Pemerintahan dan Sistem Pengendalian Intern terhadap Kualitas Laporan Keuangan Pemerintah Daerah (Studi Empiris pada SKPD Kabupaten Kerinci).

Hafiz, Abdul Tanjung. (2013). Akuntansi Pemerintah Daerah Berbasis Akrual Cetakan Kedua. Bandung: Alfabeta.

Hafiz, Abdul Tanjung. (2014). Akuntansi, Transparansi, dan Akuntabilitas Keuangan Publik. Yogyakarta: BPFE UGM.

Halim, Abdul. (2010). Sistem Akuntansi Sektor Publik. Yogyakarta: UPP STIM YKPN. 
Hasibuan, Malayu. (2012). Manajemen Sumber Daya Manusia. Jakarta: PT. Bumi Aksara.

Harahap, Aida Fikri. (2015). Pengaruh Penerapan Sistem Akuntansi Keuangan Pemerintah Daerah Terhadap Kualitas Laporan Keuangan Pemerintah Daerah (Studi Kasus Pada Seluruh SKPD di Provinsi Sumatera Utara). Skripsi. USU. Medan.

Hutapea Parulian dan Nurianna. 2008. Kompensasi Plus, Jakarta: PT. Gramedia Pustaka Utama.

Made Ayu Darmayani, Nyoman Trisna Herawati, dan Anantawikra Tungga Atmaja. (2014). Pengaruh Kualiatas Sumber Daya Manusia, Penerapan Informasi Pengelolaan Keuangan Daerah (SIKPD) Dan Pengendalian Intern terhadap Nilai Laporan Keuangan pada Bagian Keuangan Setda Kabupaten Bulelen. eJournal S1 Ak Universitas Pendidikan Ganesha Jurusan Akuntansi Program S1, Volume 2 NO.1.

Mulyana, Imam. (2010). Sumber Daya Manusia. Edisi Kedua. Jakarta: Salemba Empat.

Nurul, Sri Fajri. (2013). Pengaruh Ukuran Perusahaan, Struktur Kepemilikan dan Konsentrasi Pasar Terhadap Kualitas Laporan Keuangan.

Peraturan Menteri No.58 Tahun 2005. Tentang Pengelolaan Keuangan Daerah.

Keuangan No.59/PMK.06.2005 Tahun 2005. Tentang Sistem Akuntansi dan Pelaporan Keuangan Pemerintah Pusat

Pemerintah No.71 Tahun 2010. Tentang Standar Akuntansi Pemerintahan.

Dalam Negeri No.59 Tahun 2007. Tentang Perubahan Atas Peraturan Menteri Dalam Negeri No. 13 Tahun (2006) tentang Pedoman Pengelolaan Keuangan Daerah.

Dalam Negeri No.21 Tahun 2011. Tentang Perubahan Atas Peraturan Menteri Dalam Negeri No. 13 Tahun (2006) tentang Pedoman Pengelolaan Keuangan Daerah.

Pemerintah No.8 Tahun 2006. Tentang Pelaporan Keuangan dan Kinerja Instansi Pemerintah.

. Pemerintah No.17 Tahun 2010. Tentang Pengertian Laporan Keuangan.

Pemerintah No.24 Tahun 2010. Tentang Standar Akuntansi Pemerintah (SAP) Peraturan Pemerintah No. 58 Tahun 2005 mengenai Pengelolaan Keuangan Daerah. 

Daerah.

. Daerah No.11 Tahun 2016. Tentang Pembentukan dan Susunan Perangkat

Roviyanti, Devi. (2011). Pengaruh Kompetensi Sumber Daya Manusia Dan Penerapan Sistem Akuntansi Keuangan Daerah Terhadap Kualitas Laporan Keuangan Daerah (Survei Pada Organisasi Perangkat Daerah (OPD) Kabupaten Tasikmalaya).

Saifuddin Azwar. (2012). Penyusunan Skala Psikologi, Edisi 2. Yogyakarta: Pustaka Pelajar.

Soekidjo, Notoatmojo. (2009). Pengembangan Sumber Daya Manusia. Jakarta: Rineka Cipta.

Sugiyono. (2013). Statistika untuk Penelitian, CV. Alfabeta. Bandung.

Triwardana, Dhedy. (2107). Pengaruh Penerapan Standar Akuntansi Pemerintahan, Penerapan Sistem Akuntansi Keuangan Daerah Dan Kompetensi Sumber Daya Manusia terhadap Kualita Laporan Keuangan SKPD.

Undang-Undang Republik Indonesia No. 22 Tahun. (1999). Tentang Perubahan atas Undang-Undang Republik Indonesia No. 32 Tahun 2004 tentang Pemerintah Daerah .

- No. 33 Tahun. (2004). Tentang Perimbangan Keuangan antara Pemerintahan Pusat dan Pemerintahan Daerah.

Zarzani. (2016). Analisis Penerapan Sistem Akuntansi Keuangan Daerah Pada SKPD Pemerintah Aceh (Studi Pada Dinas Tenaga Kerja Dan Mobilitas Penduduk Aceh. 